\title{
Animasi Berbasis Multimedia Untuk Siswa Berupa Pengenalan Moda Transportasi Dengan Metode Waterfall
}

\author{
Ibnu Dwi Lesmono, M.Kom \\ Universitas Bina Sarana Informatika \\ Email: Ibnu.Idl@bsi.ac.id
}

\begin{abstract}
Abstrak
Media pendukung pembelajaran bagi siswa sekolah dasar memiliki banyak variasi teknik penyampaian, baik ada yang berbentuk media audio maupun video. Salah satu media penyampaian bagi pembelajaran siswa yaitu berbasis multimedia yang menjadi rancangan aplikasi dalam penelitian ini. Kemampuan mengenali berbagai macam alat transportasi massal bagi tingkat sekolah dasar perlu dikembangkan agar siswa mampu dengan mudah mengetahui dengan baik alat macam macam alat transportasi massal, hal ini yang menjadi tujuan dalam penelitian ini, yaitu merancang suatu aplikasi multimedia pengenalan alat transportasi . Dengan menggunakan teknik pengumpulan data observasi dan studi kepustakaan, objek dalam penelitian ini adalah SDN Cipondoh 9 Tangerang, dimana siswa-siswi dijadikan acuan utama dalam mendukung perancangan aplikasi ini. Perancangan aplikasi multimedia penelitian ini menggunakan model waterfall dalam pengembangan aplikasi. Sedangkan untuk tahap pengujian aplikasi, peneliti menggunakan teknik pengujian black box testing. Maka berdasarkan pemikiran tersebut, dibuat aplikasi pembelajaran transportasi massal berbasis multimedia yang dibuat dengan software Adobe Flash CS3, Basis data, yang diharapkan dengan adanya aplikasi ini dapat membantu proses belajar mengajar Di Sekolah.
\end{abstract}

Kata Kunci: Aplikasi, Multimedia Flash, Tranportation, Waterfall

\begin{abstract}
Learning media support for elementary school students has many variations of delivery techniques, both in the form of audio and video media. One of the delivery media for student learning is multimedia-based which is the application design in this study. The ability to recognize various kinds of mass transportation tools for elementary school level needs to be developed so that students are able to easily know the kinds of mass transportation equipment, this is the goal in this study, namely designing a multimedia application introduction of mass transportation equipment. By using observation and literature study data collection techniques, the object in this study was Cipondoh 9 Public Elementary School in Tangerang, where students were used as the main reference in supporting the design of this application. The design of multimedia application of this research using waterfall model in application development. While for the application testing phase, researchers used black box testing testing techniques. So based on this thought, in this final report was made a multimedia-based mass transportation learning application created with Adobe Flash CS3 software, Database, which is expected with this application can help the teaching and learning process in schools.
\end{abstract}

Keywords: Application, Multimedia Flash, Tranportation, Waterfall 


\section{Pendahuluan}

Media pembelajaran yang efektif akan sangat berpengaruh terhadap kemampuan siswa dalam memahami materi pelajaran yang di sampaikan di kelas. Bila media pembelajaran bersifat manual diberikan secara terus menerus atau guru menjelaskan secara teori dari sumber referensi yang ada, maka penyerapan ilmu siswa pun dirasa membosankan, terlebih ditingkat sekolah dasar. diperlukan inovasi media pembelajaran yang digunakan untuk meningkatkan kualitas pembelajaran, salah satu produk teknologi.(Hardiyan \& Fajriyah, 2017). perlu adanya metode belajar mengajar yang dapat di guanakan oleh guru dan siswa sebagai media pembelajar yang baik. (Fridayanthie, Mochammad Abdul Azis, \& Aliffah Kusumaningrum, 2018) Salah satu ilmu yang dipelajari oleh siswa sekolah dasar adalah pengetahuan mengenal berbagai macam alat transportasi massal. informasi seputar alat alat transportasi yang ada di negara Indonesia, baik yang ada di darat, udara maupun laut tentunya akan menambah pengetahuan siswa siswi. Penyampaian ilmu yang diberikan untuk kasus ini, tentu saja tidak bisa hanya sebatas penyampaian secara lisan saja oleh guru, tetapi dibutuhkan media pendukung sebagai sarana penyampaian ilmu pengetahuan dan wawasan. SDN Cipondoh 9 Tangerang dijadikan objek dalam penelitian ini. Kemampuan siswa-siswi SDN Cipondoh 9 Tangerang mengenal alat alat transportasi di Indonesia dijadikan fokus dalam perancangan aplikasi multimedia dalam penelitian ini. Perancangan aplikasi multimedia ini akan membantu siswa dalam meningkatkan pengetahuan mengenal alat alat transportasi massal. Peran guru dalam menyampaikan materi pembelajaran pun dapat terbantu karena secara visual aplikasi dibuat menarik sesuai dengan tingkatan usia siswa sekolah dasar. Selain mendapat ilmu dari guru dikelas, siswa dapat memanfaatkan aplikasi multimedia

yang dirancang untuk dapat membantu proses belajar mengajar disekolah. Masalah penelitian dalam penelitian ini adalah peran guru di SDN Cipondoh 9 Tangerang dalam penyampaian materi pembelajaran masih bersifat teoritis, khususnya mengenai informasi seputar alat alat transportasi.

Sedangkan rumusan masalah dalam penelitian ini, yaitu Bagaimanakah merancang suatu aplikasi multimedia yang dapat membantu guru serta menunjang dalam penyampaian materi pengetahuan mengenal alat alat transportasi pada SDN Cipondoh 9 Tangerang. Penelitian ini bertujuan untuk membantu meningkatkan pengetahuan serta wawasan para siswa siswi mengenai alat alat transportasi bagi siswa SDN Cipondoh 9 Tangerang dan mampu dengan mudah mengetahui bentuk dari berbagai macam alat transportasi. Dengan adanya rancangan aplikasi multimedia mengenal alat alat transportasi. Sedangkan manfaat dari penelitian ini, yaitu, rancangan aplikasi ini diharapkan dapat menjadi penunjang untuk guru dalam sistem belajar mengajar pada dunia pendidikan dan memberikan materi tentang mode Transportasi . Ruang lingkup dalam penelitian ini hanya dibatasi dari segi perancangan aplikasi multimedia pengenalan alat alat transportasi , dengan menggunakan metode pengembangan aplikasi model waterfall.

\section{A. Aplikasi Multimedia}

Aplikasi adalah kumpulan perintah program yang dibuat untuk melakukan pekerjaan-pekerjaan tertentu. (Hendrayudi, 2009)

Sedangkan multimedia adalah media yang menggabungkan dua unsur atau lebih media yang terdiri dari teks, grafis, gambar, foto, audio, video dan animasi secara terintegrasi.(Ichwan Kurniawan, 2015)

Aplikasi multimedia sering dimanfaatkan juga dalam dunia pendidikan dan bisnis. Didunia pendidikan, multimedia digunakan sebagai sarana pengajaran, baik dalam kelas maupun secara individual Berdasarkan pengertian ini, maka multimedia dapat dibedakan menjadi tiga jenis, diantaranya adalah:

a) Multimedia Interaktif

Pengguna dapat mengontrol apa dan kapan elemen-elemen multimedia akan ditampilkan. Contoh: world wide web, mobile banking, game online, website.

b) Multimedia Hiperaktif

Multimedia jenis ini mempunyai suatu struktur dari elemen-elemen terkait dengan pengguna yang dapat mengarahkannya. Dapat dikatakan bahwa multimedia jenis ini mempunyai 
banyak tautan (link) yang menghubungkan elemen-elemen multimedia yang ada. Contoh: game, CD interaktif, aplikasi program, virtual reality.

c) Multimedia Linier

Pengguna hanya menjadi penonton dan menikmati produk multimedia yang disajikan dari awal hingga akhir. Contoh: film, musik, e-book, TV.

\section{B. Animasi}

Animasi pada dasarnya merupakan kumpulan image sekuensial (berurutan) yang menyatakan pergerakan, dimana image tersebut ditampilkan secara berurutan dalam waktu yang relatif cepat. (Ichwan Kurniawan, 2015) Saat ini animasi tidak hanya digunakan untuk media hiburan saja, tetapi animasi banyak digunakan sebagai media penunjang bagi pembelajaran didunia pendidikan, baik pendidikan formal maupun nonformal.

Animasi merupakan kumpulan gambar yang diolah sedemikian rupa sehingga menghasilkan gerakan, perubahan visual sepanjang waktu yang memberikan kekuatasn besar pada proyek multimedia. (Hendrayudi, 2009)

Saat ini banyak aplikasi multimedia yang mengediakan fasilitas animasi. Dahulu animasi mempunyai prinsip sederhana, namun sekarang telah berkembang menjadi beberapa jenis. Berikut beberapa jenis animasi (Suheri, 2006) :

a) Animasi 2D (Dua Dimensi)

Animasi ini yang paling akrab dengan keseharian kita. Biasa disebut juga dengan film kartun. Kartun sendiri berasal dari kata Cartoon, yang berarti gambar lucu. Memang film kartun ini kebanyakan film yang lucu. Contoh dari film 2D adalah Shincan, Looney Tunes, Pink Panther, Tom and Jerry, dan Scooby Doo.

b) Animasi 3D (Tiga Dimensi)

Perkembangan teknologi dan dunia komputer membuat teknik pembuatan animasi 3D semakin berkembang dan maju pesat. Animasi 3D adalah perkembangan dari animasi 2D. Dengan animasi 3D, karakter yang diperlihatkan semakin hidup dan nyata, mendektati wujud asli. Contoh film dengan menggunakan animasi 3D adalah Bugs
Life, Antz, Toy Story, Monster Inc, Final Fantasy, hingga Finding Nemo.

c) Animasi Tanah Liat (Clay Animation) Meski namanya Clay (tanah liat), namun yang dipakai bukanlah tanah liat biasa. Animasi ini menggunakan plasticin, bahan lentur seperti permen karet yang ditemukan pada tahun 1897. Tokoh-tokoh pada animasi clay dibuat dengan menggunakan rangka khusus untuk kerangka tubuhnya, baru kemudian dilapisi dengan plasticin. Contoh penerapan pada film animasi ini adalah Chicken Run dari Dream Work Pictures.

\section{Editor Multimedia Flash}

Dalam perancangan aplikasi penelitian ini, peneliti menggunakan salah satu editor multimedia flash yang mudah digunakan, yaitu adobe flash yang merupakan salah satu produk perangkat lunak komputer unggulan yang dikeluarkan oleh Adobe Systems sebagai editor multimedia flash untuk membuat gambar vektor maupun animasi gambar.(Ichwan Kurniawan, 2015)

Sedangkan untuk versi yang digunakan dalam perancangan aplikasi penelitian ini, menggunakan Adobe Flash Professional CS6 yang merupakan sebuah software yang didesain khusus oleh Adobe dan program aplikasi standar authoring tool professional dan biasa juga digunakan untuk membuat animasi dan bitmap yang sangat menarik . (Ichwan Kurniawan, 2015) Adobe Flash CS6 menyediakan berbagai macam fitur yang akan sangat membantu para animator untuk membuat animasi menjadi semakin mudah dan menarik. Adobe Flash CS6 telah mampu membuat dan mengolah teks maupun objek dengan efek tiga dimensi, sehingga hasilnya tampak lebih menarik.

\section{Storyboard}

Storyboard adalah sketsa gambar yang disusun berurutan sesuai dengan naskah, dengan storyboard kita dapat menyampaikan ide cerita kita kepada orang lain dengan lebih mudah, karena kita dapat menggiring khayalan seseorang mengikuti gambargambar yang tersaji, sehingga menghasilkan persepsi yang sama pada ide cerita kita [1]. 
Storyboard mempunyai peranan sangat penting dalam pengembangan multimedia, digunakan sebagai alat bantu pada tahapan perancangan aplikasi multimedia.

\section{E. Black Box Testing}

Black box testing merupakan salah satu teknik pengujian aplikasi perangkat lunak, dimana teknik pengujian ini memungkinkan kita untuk membuat beberapa kumpulan kondisi masukan yang sepenuhnya akan melakukan semua kebutuhan fungsional untuk program.(Roger S Pressman, 2012) Pengujian black box bukan teknik alternatif untuk white box. Sebaliknya, ini merupakan pendekatan pelengkap yang mungkin dilakukan mengungkapkan kelas kesalahan yang berbeda dari yang diungkap oleh metode white box. Pengujian black box testing berupaya untuk menemukan kesalahan dalam kategori berikut:

a) Fungsi yang salah atau hilang

b) Kesalahan antarmuka

c) Kesalahan dalam struktur data atu akses basis data eksternal

d) Kesalahan perilaku atau kinerja

\section{F. Model Pengembangan Software Waterfall}

Model SDLC (Software Development Life Cycle) air terjun (Waterfall) sering juga disebut model sekuensi linier (Sequential liniar) atau alur hidup klasik (classic life cycle)". Model air terjun menyediakan pendekatan alur hidup perangkat lunak secara sekuensial atau terurut dimulai dari analisis, desain, pengodean, pengujian, dan tahap pendukung (support).(Rosa A.S \& Shalahudin, 2013) Yang terbagi menjadi lima tahapan, yaitu: Berikut adalah gambar model air terjun:

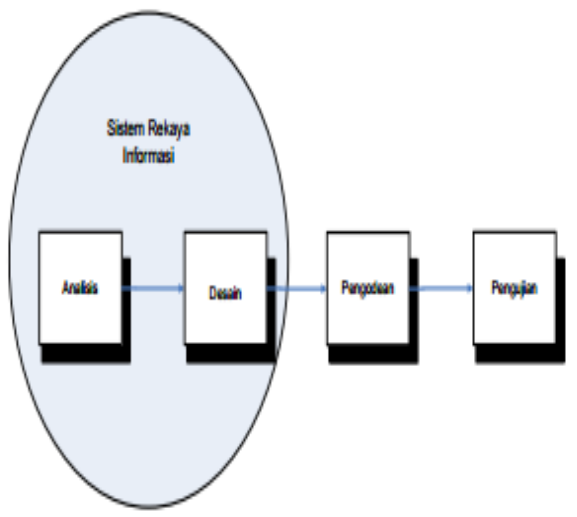

Gambar 1. Ilustrasi Model Waterfall

Sumber :(Rosa dan Shalahudin:2013)

Metode yang digunakan pada rancang bangun sistem informasi dalam penelitian ini menggunakan model waterfall yang terbagi menjadi lima tahapan. (Hendrayudi, 2009)

a) Analisis Kebutuhan Perangkat Lunak Proses pengumpulan kebutuhan dilakukan secara intensif untuk menspesifikasikan kebutuhan perangkat lunak agar dapat dipahamai perangkat lunak seperti apa yang dibutuhkan oleh user. Spesifikasi kebutuhan perangkat lunak pada tahap ini perlu untuk didokumentasikan.

b) Desain

Desain perangkat adalah proses multi langkah yang fokus pada desain pembuatan program perangkat lunak termasuk struktur data, arsitektur perangkat lunak, representasi antarmuka, dan prosedur pengodean. Tahap ini menstralasi kebutuhan perangkat lunak dari tahap analisis kebutuhan ke representasi desain agar diimplementasikan menjadi program pada tahap selanjutanya. Desain perangkat lunak yang dihasilkan pada tahap ini juga perlu di dokumentasikan.

c) Pembuatan Kode Program

Desain harus ditranlasikan ke dalam program perangkat lunak. Hasil dari tahap ini adalah program komputer sesuai desain yang telah dibuat pada tahap desain.

d) Pengujian 
Pengujian fokus pada perangkat lunak secara logik dan fungsional dan memastikan bahwa semua bagian sudah di uji. Hal ini dilakukan untuk meminimalisir kesalahan (error) dan memastikan keluaran yang dihasilkan sesuai dengan yang diinginkan.

e) Pendukung (Support) dan Pemeliharaan (Maintenance)

Tidak menutup kemungkinan sebuah perangkat lunak mengalami perubahan ketika sudah dikirimkan ke user. Perubahan bisa terjadi karena adanya kesalahan yang muncul dan tidak terdeteksi saat pengujian atau perangkat lunak harus beradaptasi dengan lingkungan baru. Tahap pendukung atau pemeliharaan dapat mengulangi proses pengembangan mulai dari analisis spesifikasi untuk perubahan perangkat lunak yang sudah ada, tapi tidak untuk membuat perangkat lunak baru.

\section{Metode Penelitian}

Dalam penelitian ini, metode pengumpulan data yang digunakan, adalah metode observasi dan studi kepustakaan dengan model water fall berikut penjabarannya:

a) Peneliti menggunakan metode observasi dengan mengamati secara langsung objek penelitian untuk mendapatkan analisa kebutuhan dari aplikasi multimedia yang akan dirancang.

b) Peneliti juga mencari sumber referensi yang dijadikan acuan penelitian dari berbagai studi literatur, baik sumber yang berasal dari buku maupun sumber dari internet.

\section{A. Model Waterfall}

Dalam perancangan aplikasi multimedia penelitian ini, peneliti menggunakan model pengembangan aplikasi waterfall. Berikut tahapan yang telah dilakukan:

1. Analisa Kebutuhan Perangkat Lunak Peneliti terlebih dahulu melakukan pengumpulan data dengan melakukan observasi pada objek penelitian. Datadata yang dikumpulkan seperti pengetahuan seputar alat alat transportasi massal yang telah dipelajari pada objek penelitian, analisa kebutuhan user atau pihak yang akan jadi target penggunaan aplikasi, serta kebutuhan-kebutuhan sistem dari aplikasi yang akan dirancang.

Aplikasi multimedia penelitian ini dirancang untuk dijadikan media penunjang pembelajaran bagi siswa dalam mendapatkan pengetahuan seputar alat alat Transportasi Masal Berikut beberapa hal mengenai tahapan yang dilakukan dalam analisa spesifikasi kebutuhan perangkat lunak untuk aplikasi yang dirancang, diantaranya yaitu:

a) Peneliti melakukan analisa seputar wawasan pengetahuan alat alat transportasi massal yang diberikan guru kepada siswa SDN Cipondoh 9 Tangerang.

b) Peneliti melakukan analisa mengenai user yang akan menggunakan aplikasi beserta karakteristik dari user tersebut terhadap penggunaan teknologi multimedia.

c) Peneliti melakukan analisa terhadap user interface dan spesifikasi kebutuhan aplikasi yang disesuaikan dengan kebutuhan user.

\section{Desain}

Setelah tahapan analisa kebutuhan perangkat lunak dilakukan, maka tahapan selanjutnya peneliti melakukan perancangan desain dari aplikasi multimedia penelitian ini. Desain rancangan aplikasi multimedia ini menggunakan storyboard sebagai dokumentasi perancangan aplikasi.

a) Pembuatan Kode Program Dalam tahapan pembuatan kode program, peneliti menggunakan editor aplikasi multimedia Adobe Flash untuk merancang dan membuat aplikasi kedalam media komputer berdasarkan desain sebelumnya dalam bentuk dokumentasi, dalam tahapan ini terdapat pula kegiatan, seperti penulisan kode program, memasukan objek gambar, video, latar belakang menu aplikasi serta suara yang dibutuhkan.

b) Pengujian

Setelah aplikasi selesai dirancang, kemudian peneliti melakukan pengujian aplikasi dengan 
menggunakan metode Black Box Testing. Proses pengujian terhadap aplikasi fokus terhadap proses masukan dan keluaran yang terdapat pada aplikasi multimedia yang dirancang.

c) Pendukung(Support) dan Pemeliharaan (Maintenance) Dalam tahapan ini peneliti secara berkala akan melakukan pembaharuan (update) data aplikasi sesuai dengan perkembangan teknologi software dan hardware terkini agar siklus hidup aplikasi berjalan dengan baik.

\section{Hasil Dan Pembahasan}

\subsection{Analisa Kebutuhan Aplikasi}

Berdasarkan penelitian yang telah dilakukan, berikut hasil analisa kebutuhan perancangan aplikasi multimedia flash

pengenalan moda transportasi Di SDN Cipondoh 9 Tangerang:

1) Aplikasi yang dirancang harus dapat menampilkan berbagai bentuk moda transportasi massal yang ada di Indonesia dalam bentuk animasi interaktif

2) Aplikasi yang dirancang menampilkan informasi

3) mengenai pengenalan moda transportasi massal yang ada di Indonesia.

4) Aplikasi yang dirancang mampu menampilkan informasi mengenai moda transportasi massal dalam bentuk video dan audio.

5) Aplikasi yang dirancang harus dapat digunakan dengan mudah untuk siswa sekolah dasar dengan tampilan dan menu yang user friendly.

6) Aplikasi yang dirancang menyediakan media latihan-latihan soal dari materi yang disediakan, sebagai bahan evaluasi dari penggunaan aplikasi.

\section{A. Identifikasi Kebutuhan}

a) Mempersiapkan bahan
Penulis dapat Mengambil bahan untuk membuat sebuah animasi ini, seperti gambar-gambar dan keterangan dari berbagai buku yang menjelaskan tentang sejarah transportasi masal, dan situs-situs yang memuat tentang transportasi.

b) Teks

Teks atau isi materi pada pembuatan aplikasi ini, penulis peroleh dari Buku tentrang alat transportasi dan perkembangannya.

c) Gambar

Gambar dibuat menggunakan Adobe Flash CS3, animasi pada aplikasi ini penulis buat menjadi animasi menggunakann Adobe Flash CS3.

d) Animasi

Animasi pada aplikasi ini penulis buat menjadi animasi menggunakann Adobe Flash CS3.

e) Suara

Suara digunakan untuk suara latar pada setiap halaman yang disediakan.

\section{f) Tombol Navigasi}

Tombol navigasi yang terdapat dalam aplikasi ini mengandung tautan (link) yang dapat menghubungkan satu halaman dengan halaman yang lain.

Tabel 1. Tombol Navigasi

\begin{tabular}{|l|l|l|}
\hline No. & Gambar tombol & Keterangan \\
\hline 1. & $\begin{array}{l}\text { Tombol ini berfungsi } \\
\text { untuk menuju ke } \\
\text { halaman menu utama }\end{array}$ \\
\hline 2. & $\begin{array}{l}\text { Tombol ini berfungsi } \\
\text { untuk menuju kembali } \\
\text { ke menu utama }\end{array}$ \\
\hline 3. & $\begin{array}{l}\text { Tombol ini berfungsi } \\
\text { untuk menuju materi }\end{array}$ \\
\hline 4. & $\begin{array}{l}\text { Tombol ini berfungsi } \\
\text { untuk menuju materi }\end{array}$ \\
\hline 5. & $\begin{array}{l}\text { Tombol ini berfungsi } \\
\text { untuk menuju materi. }\end{array}$ \\
\hline 7. & $\begin{array}{l}\text { Tombol ini berfungsi } \\
\text { untuk menuju soal } \\
\text { materi. }\end{array}$ \\
\hline
\end{tabular}




\subsection{Perancangan Animasi}

Pada tahap perancangan, penulis melakukan rancangan aplikasi yang terdiri dari perancangan Storyboard.

a) Materi

Pada halaman materi terdiri atas 4 materi. Diharapkan anak dapat membaca, mempelajari dan memahami penjelasan-penjelasan pada halaman materi ini.

b) Latihan

Pada halaman latihan disediakan soal dalam bentuk pilihan ganda. Tujuan adanya latihan ini untuk menguji kemampuan anak setelah memahami materi yang diberikan.

c) Profil

Pada halaman profil, akan ditampilkan sebuah data profil penulis.

d) Penulisan Story Board

e) Setting dan sinopsis

Setting awal merupakan tampilan kendaran yang di pakai secara masal untuk mengetahui sejarah tiap transportasi sang anak harus memilih kendaran masal dengan cara mengklik icon kendaran masal yang akan di bacanya, lalu muncul tampilan text sejarah transportasi masal yang telah di pilih, Sinopsis pengenalan transportasi masal ini memiliki alur cerita sebagai berikut. Di dalam tiap icon kendaran masal yang di pilih terdapat sejarah dan pengembangan tiap transportasi yang di pilih, Setelah membuka semua icon kendaran masal maka anak di wajibkan membuka icon latihan materi yang di mana terdapat latihan soal yang berjumlah 20 soal jika menjawab benar akan terus kesoal selanjutnya dan mendapatkan nilai 1 di setiap soal, jika menjawab salah maka akan muncul text yang berisikan lebih giat belajar lagi dan jika terus bisa menjawab tiap soal maka akan terlihat text selamat nilai kamu 10.

a) Desain Aplikasi

Rancangan animasi ini di buat dalam bentuk form yang di pecah dalam beberapa beberapa bagian guna membagi keterangan aplikasi yang akan di kerjakan secara rinci. Rincian keterangan ini mempermudah dalam proses pembuatan aplikasi tentang pengenalan transportasi masal. Secara lengkap desain aplikasi dibuat seperti tampilan di bawah ini:

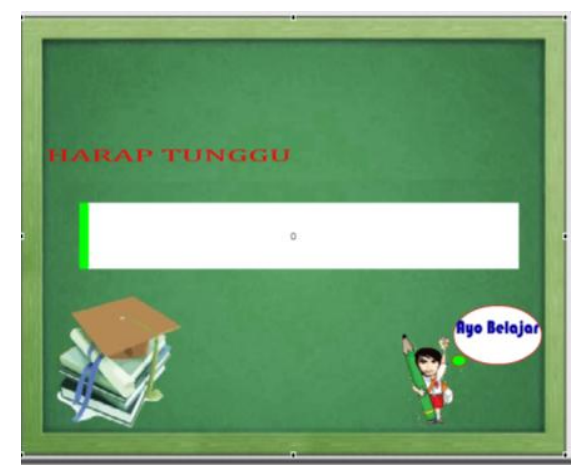

Gambar 2. Tampilan Loading

Keterangan tampilan :

1. Pada bagian tengah animasi loading

2. Bagian kanan bawah icon karakter

3. Bagian kiri atas text loading

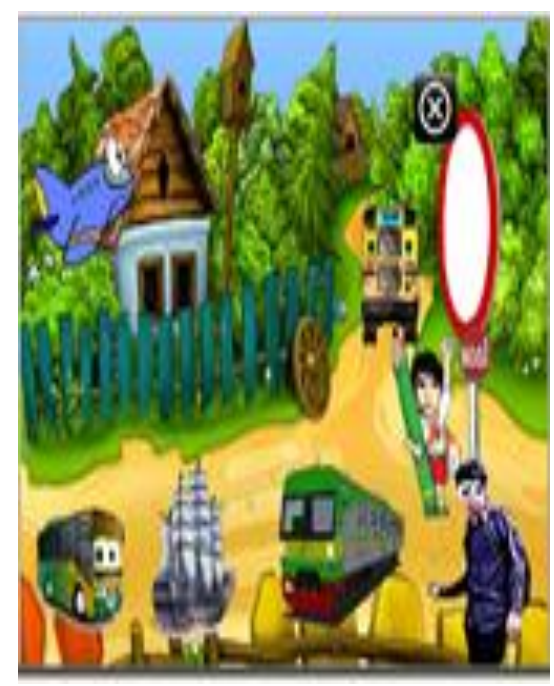

Gambar 3. Tampilan Awal 


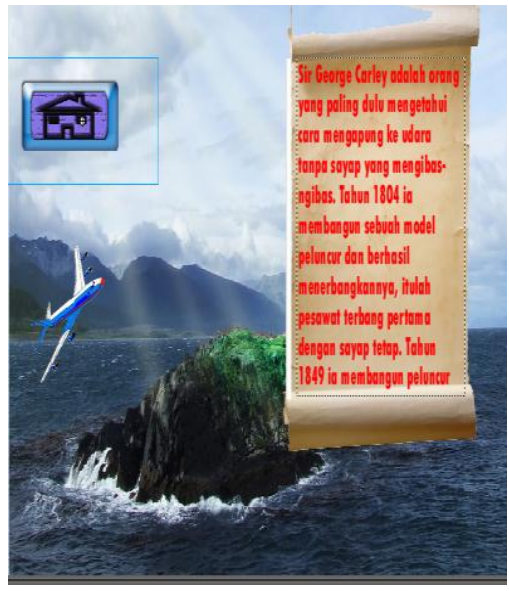

Gambar 4. Tampilan menu pesawat terbang

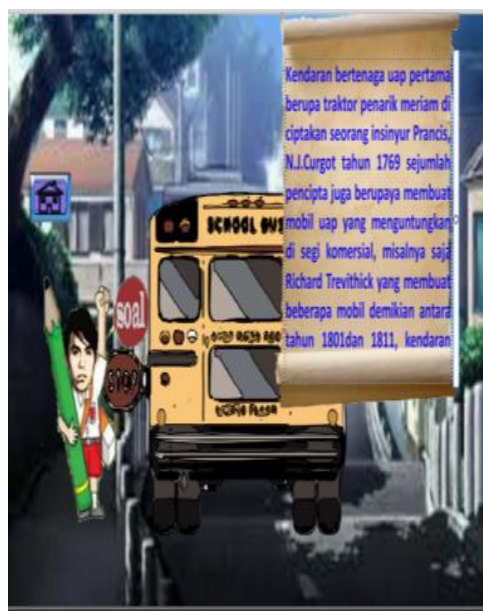

Gambar 5. Tampilan Menu Bus

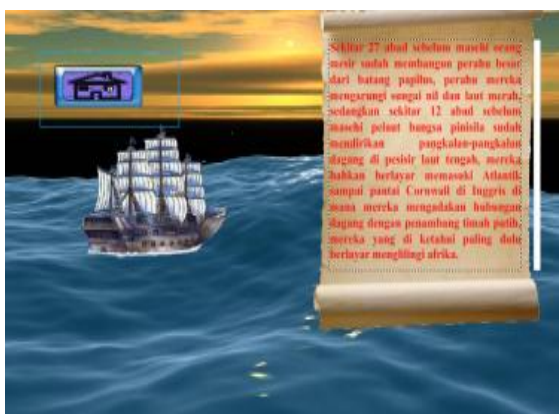

Gambar 6. Tampilan Menu kapal laut

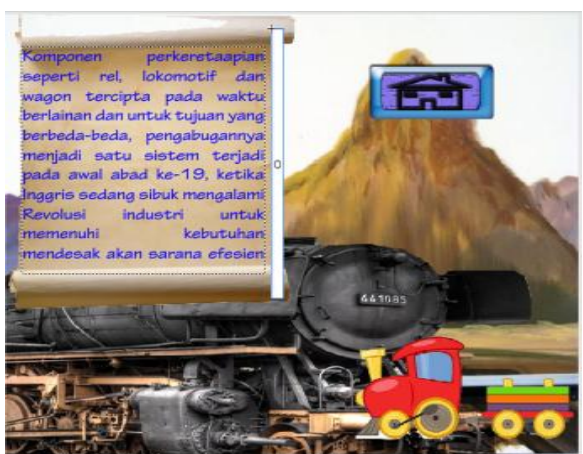

Gambar 7. Tampilan menu kereta Api

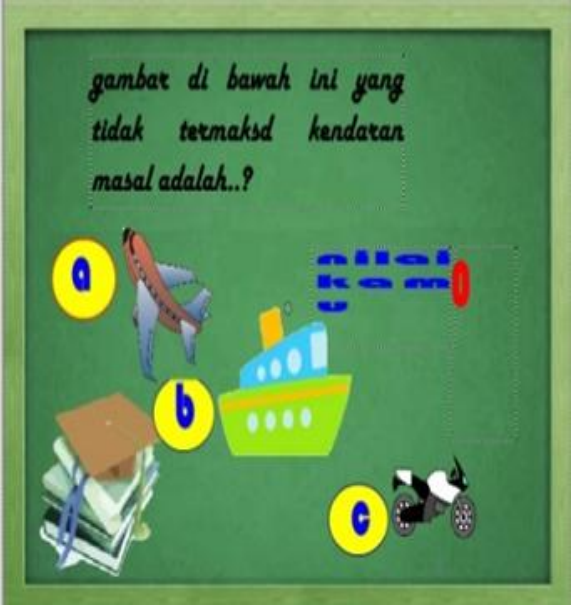

Gambar 8.

Tampilan Menu Latihan

\section{$4 \quad$ Pengembangan Animasi}

\section{A. Perloading}

Halaman per-loading dari pembelajaran pengenalan animasi interaktif yang berisi batang yang maju yang di berikan hitungan maju 1 detik untuk menuju ke menu utama. Berikut actions yang digunakan:

stop();

\section{B. Menu}

Halaman menu dari pembelajaran pengenalan animasi interaktif yang berisi tombol materi pesawat terbang, tombol materi bus, tombol materi kapal laut, tombol profil, tombol materi kereta api, 
tombol materi soal pilihan ganda, tombol untuk keluar aplikasi.

Berikut actions yang digunakan: on (release) \{ \}

on (release) \{ gotoAndPlay("kapal", 1);<smiles>[CH][TlH]</smiles>

\} on (release) \{ gotoAndPlay(keretat", 1); \} on (release) \{ gotoAndPlay("latihan", 1); nilai $=0$;

\} on (release) \{ \}

1. Halaman Bus

Halaman bus dari pembelajaran pengenalan animasi interaktif yang berisi tentang materi dan sejarah bus serta perkembangannya.

Berikut actions yang digunakan:

on (release) \{

\}

on (release) \{

gotoAndPlay("menu", 1);

2. Pesawat terbang

Halaman pesawat terbang dari pembelajaran pengenalan animasi interaktif yang berisi tentang materi dan sejarah dan pencetus mengapung ke udara pertama tanpa sayap pertama serta perkembangannya.

Berikut actions yang digunakan:

on (release) \{ gotoAndPlay("menu", 1);

3. Kapal laut

Halaman kapal laut dari pembelajaran pengenalan animasi interaktif yang berisi tentang materi dan sejarah dan pencetus mengapung ke air pertama dan orangorang yang pertama kali berlayar di lautan. Berikut actions yang digunakan: on (release) \{

\} on (release) \{

4. Profil

Halaman profil dari pembelajaran pengenalan animasi interaktif yang berisi tentang biodata penulis serta tombol untuk kembali ke menu utama.

Berikut actions yang digunakan: on (release) \{

5.

Halaman kereta dari pembelajaran pengenalan animasi interaktif yang berisi tentang penegmbangan kereta api dan penemu mesin uap.

Berikut actions yang digunakan: on (release) \{

6. Halaman Latihan

Halaman latihan dari pembelajaran pengenalan animasi interaktif yang berisi tentang latihan dari pembahasan materi dan hasil nilai dari jawaban menjawab soal materi.

Berikut actions yang digunakan:

on (release) \{

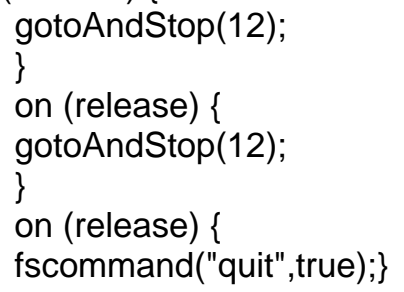

C. Black Box Testing

Berikut hasil dari pengujian black box testing terhadap proses masukan dan keluaran pada aplikasi:

\section{Pengujian Halaman Menu}

Tabel 2. Pengujian Halaman Menu

\begin{tabular}{|l|l|l|l|}
\hline Input/ & Proses & Output & Hasil \\
& & $/$ & Pengujia \\
& & Next & $\mathrm{n}$ \\
Tombol & on (release) & Tampil & Hasil \\
Materi & \{ & an & Sesuai \\
\hline
\end{tabular}

JURNAL SWABUMI Vol.7 No.1, Maret 2019: 20 30 


\begin{tabular}{|c|c|c|c|}
\hline & $\begin{array}{l}\text { gotoAndPla } \\
\begin{array}{l}\text { y(196); } \\
\text { kemana }\end{array} \\
=\text { 'materi'; } \\
\text { \} } \\
\text { Penjelasan: } \\
\text { Ketika } \\
\text { mengklik } \\
\text { tombol } \\
\text { Materi, } \\
\text { maka akan } \\
\text { tampil } \\
\text { menu }\end{array}$ & $\begin{array}{l}\text { menu } \\
\text { akan } \\
\text { keluar } \\
\text { setela } \\
\text { h } \\
\text { mengk } \\
\text { lik } \\
\text { tombol } \\
\text { materi }\end{array}$ & \\
\hline $\begin{array}{l}\text { Tombol } \\
\text { latihan }\end{array}$ & $\begin{array}{l}\text { gotoAndPla } \\
\text { y(196); } \\
\text { kemana } \\
=\text { 'quiz'; } \\
\text { \} } \\
\text { Penjelasan: } \\
\text { Ketika } \\
\text { mengklik } \\
\text { tombol } \\
\text { latihan, } \\
\text { maka akan }\end{array}$ & $\begin{array}{l}\text { Tampil } \\
\text { an } \\
\text { awal } \\
\text { Quiz } \\
\text { akan } \\
\text { muncu } \\
\text { I } \\
\text { setela } \\
\text { h } \\
\text { mengk } \\
\text { lik } \\
\text { tombol }\end{array}$ & $\begin{array}{l}\text { Hasil } \\
\text { Sesuai }\end{array}$ \\
\hline
\end{tabular}

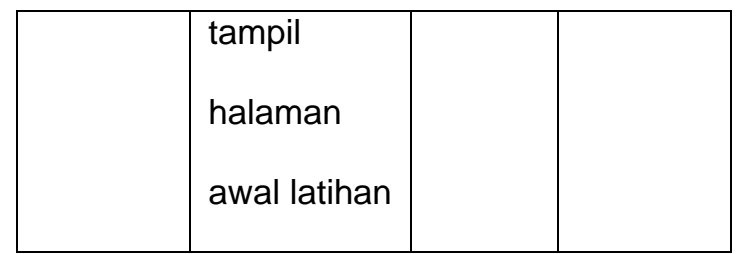

D. Pendukung Aplikasi (Support)

Berikut adalah pendukung aplikasi yang diperlukan, terbagi kedalam perangkat keras dan perangkat lunak. Penjabarannya sebagai berikut:

Perangkat keras adalah semua bagian fisik komputer, dibedakan dengan data yang berada di dalamnya atau yang beroperasi didalamnya, dan dibedakan juga dengan perangkat lunak yang menyediakan instruksi untuk perangkat keras dalam menyelesaikan tugasnya (Simarmata, 2010). Berikut spesifikasi perangkat keras aplikasi:

1. CPU (Central Processing Unit) Processor Intel Core i3

2. RAM $2,00 \mathrm{~GB}$

3. Hard Disk $320 \mathrm{~GB}$

4. Mouse PS/2

5. Keyboard

6. Monitor dengan resolusi layar 14"

Sedangkan perangkat lunak adalah instruksi langsung komputer untuk melakukan pekerjaan dan dapat ditemukan disetiap aspek kehidupan modern dari aplikasi yang kritis untuk hidup, seperti perangkat pemantau medis dan pembangkit tenaga listrik sampai perangkat hiburan

Berikut spesifikasi perangkat lunak aplikasi:

1. Sistem Operasi yang umum digunakan seperti : Microsoft Windows, dengan aplikasi yang digunakan seperti : Adobe Flash CS3 Professional.

\section{Kesimpulan}

Berdasarkan hasil penelitian yang telah dilakukan mulai dari tahapan analisa kebutuhan hingga tahapan pengujian dan implementasi aplikasi, maka dapat ditarik beberapa kesimpulan sebagai berikut:

1. Aplikasi berbentuk multimedia flash merupakan media menarik bagi siswa 
JURNAL SWABUMI, Vol. 7 No. 1 Maret 2019, pp. 20 30

ISSN: 2355-990X

E-ISSN:2549-5178

sekolah dasar, khususnya di SDN

Cipondoh 9 Tangerang, dalam

penyampaian dan menambah wawasan ilmu pengetahuan seputar Alat alat tranportasi umum yang di gunakan oleh masyarakat..

2. Siswa-siswi tingkat sekolah dasar dapat dengan mudah dan cepat dalam menggunakan aplikasi, bila rancangan antar muka (user interface) didesain sesuai kebutuhan dari user atau pangguna.

3. Guru mendapatkan media penunjang penyampaian materi dari aplikasi multimedia flash ini, selain penyampaian yang biasa dilakukan dikelas secara lisan.

4. Pengembangan aplikasi masih bisa dilakukan dipenelitian lebih lanjut dengan penambahan fitur-fitur informasi kendaraan tranportasi massal di Indonesia.

\section{REFERENSI}

Fridayanthie, E. W., Mochammad Abdul Azis, \& Aliffah Kusumaningrum. (2018). Rancang Bangun Sistem Informasi Perpustakaan Berbasis Web Pada Smk Citra Negara Depok. Swabumi, 6(1), 1322.

Hardiyan, \& Fajriyah, I. (2017). Animasi Interaktif Berbasis Multimedia Dalam Mempelajari. Swabumi, 5(2), 20152018.

Hendrayudi. (2009). Pengertian Aplikasi. Yogyakarta: Andi Offset.

Ichwan Kurniawan. (2015). Membuat Metode Pembelajaran Dengan Adobe Flash CS6. Yogyakarta: Andi Offset.

Roger S Pressman. (2012). Rekayasa Perangkat Lunak. Yogyakarta: Andi Offset.

Rosa A.S, \& Shalahudin. (2013). Rekayasa Perangkat Lunak. Bandung: Informatika.

JURNAL SWABUMI Vol.7 No.1, Maret 2019: 20 30 